\title{
JOURNAL OF THE.
}

\section{ROYAL \\ Musical \\ AsSOCIATION}

\section{Volume 138 Part 2013}

\section{CONTENTS}

A Note from the Editor

Purcell and the Reception of Luly's Scocca pur (LWV 76/3) in England:

Andrew Woolicy

Proliciscere, antima Christiana : Gerontus and Goman Mysticism

Aidan 2. Thomson

The London Symphony Orchestra: The First Decade Fevisited

Simon MeVeigh

Puting the BBC and T. Beecham to Shama

The Macnaghten-Lemare Concerts, $1931-7$

Sophie Fuller

\section{Revlew Articles}

Of Telescopes and Lenses, Bindness and insight

Suzannah Clark Analyzing Schubert; Janet Schmalieldi, In the Process

of Becoming: Analytic and Phibeophical Persooctives on Fom

in Eanly Ninelcenti-Cemtury Music

Michael Spitzer

Once Again: Scholarship and the Musical

The Oxfard Handbook of the American Musicale

ed. Faymond Krapp, Mitchell Morris and Stacy Woif

Stephen Banfield 